\title{
Certificates and certification programmes for clinical excellence: A guide to international pharmacists
}

\author{
Mohammed Salim Karattuthodi ${ }^{1}$ iD , Shabeer Ali Thorakkattil ${ }^{2 *}$ iD , Sainul Abideen Parakkal ${ }^{2}$ D , Ajmal \\ Karumbaru Kuzhiyil $^{3}$ iD, Anitha Jose Subin ${ }^{4}$ iD , Thahani $^{1}$ iD \\ ${ }^{1} \mathrm{Al}$ Shifa College of Pharmacy, Kerala University of Health Sciences, India \\ 2Johns Hopkins Aramco Healthcare (JHAH), Saudi Arabia \\ ${ }^{3}$ Saqr Hospital, United Arab Emirates \\ ${ }^{4}$ Life Pharmacy Group, United Arab Emirates
}

\author{
Keywords \\ American society of health-system pharmacist \\ Board certified pharmacist \\ Continuing education \\ Pharmacy certification \\ Pharmacist \\ Resource guide \\ Society of infectious diseases pharmacy

\section{Correspondence} \\ Shabeer Ali Thorakkattil \\ Pharmacy Services Department \\ Johns Hopkins Aramco Healthcare \\ Saudi Arabia \\ tkspharma@gmail.com
}

\begin{abstract}
Pharmacy practice continues to evolve, and knowledge update is necessary to facilitate better and safer patient care. This article provides information about certificates and certification programmes hosted for international pharmacists to support their scope in advanced pharmacy practices. A pilot online survey to 59 pharmacists revealed preferences towards Board of Pharmacy Specialties (BPS), American Society of Health-system Pharmacists (ASHP) certificate, Society of Infectious Diseases Pharmacy (SIDP) Antimicrobial stewardship certificate programmes, University of Florida pharmacy certificate programmes, and Medication therapy management programme (MTM) for their certification programme. Grey literature and authentic websites of each programme were collected to provide information on each programme. This article serves as a guide for international pharmacists to know further information about certificates and certification programmes available to support them in advancing their practice.
\end{abstract}

\section{Introduction}

Demand for improved human life has advanced the healthcare sector, and the concern for enhancing physiological wellbeing has enrooted to medical reforms. Healthcare professionals being the identifier, detector, and healer is inevitable as there are high diseases prevalence with varying fatality around the world. The current era of the COVID 19 pandemic has brought widespread challenges for researchers and healthcare providers (Abd El-Aziz \& Stockand, 2020). However, because of the continuous and timely effort, the situation became somewhat under control.
Machines and information technologies are invading human resources due to their efficiency and tireless work potency, often utilised in multi-speciality hospitals. The current healthcare system has advanced robotic gadgets for continuous monitoring, surgeries, and medication segregation and dispensing. However, there are disciplines where computers fail (Kaiser et al., 2021). The professionalism and skill of healthcare providers can't be replaced with automated and programmed devices. Moreover, medical professions have to modulate their communication tone in a certain situation, especially while educating patients and the public, which electronic devices cannot (Rahman et al., n.d.; Siddique \& Chow, 2021). 
The pharmacist's role has changed drastically over the decades from simply dispensing the medicine to who works side by side with the physician, nurses, and other health workers to ensure patients' safety and efficacy (Blouin \& Adams, 2017). Enhanced team-based care and interdisciplinary education are principal components to the attainment of patient-centred care. Readmission to hospitals is often linked to poor transitions of care and inappropriate medication use (Glans et al., 2020). This emphasises the relevance of integrating clinical pharmacy care that nullifies adverse events and optimises client compliance, and pharmacists can strengthen the bond with highly emotionally and physically vulnerable populations. The cost of misuse and overuse of medicine constitutes over $10 \%$ of the total healthcare cost (Ofori-Asenso \& Agyeman, 2016). Besides financial burden, the psychological and physiological consequences may prevail to varying extents. In addition to the pharmacist's contribution in hospital settings, community pharmacy is closer to society and open for outpatient care. The perception of ordinary people about pharmacists had changed, invented for focusing on various health services on both individual and community basis (Rodgers et al., 2016).

The pharmacist employed in various specialities should abate the complication generated by irrational utilisation of medicine. They should be competent enough to stand professionally alive and show their value to society. The performance of healthcare workers is always crucial for a nation, and its extension would determine the level of the country's healthcare competency (Kak et al., n.d.). To offer a better health sector, the pharmacist should update and gain more credentials (Zogas et al., 2021). The proficiency they acquire from their pharmacy school would not be adequate. Considering the current challenges in the profession, if pharmacists have a certification in a particular area, they will be able to market themselves as vital clinician in the healthcare system. Both employers and patients will be willing to pay for their skills to provide an exceptional service to them in dealing with their disease state. When medical professional signs up for studying medicines, it should be a lifetime learning process. This brings a perfect future to pharmacists and the profession, and luckily there are a wide variety of pharmacy knowledge enhancement programmes that offer certificates and certifications. Here, the article presents some major certificate and certification programmes available globally, which would aid the pharmacist as a quick reference for pursuing the same.

\section{Methods}

Design

A grey literature search through Google Search Engine and authentic websites yielded data to inform the content of this article.

\section{Sample and data collection}

Numerous add-on courses specific to international pharmacists were identified. Official websites of reputed authorities that issue pharmacist's quality improvement programmes were browsed. The search term employed were 'pharmacy certificate', 'certification programme', and 'quality improvement', enhanced by Boolean operators.

A pilot survey was conducted through google form among 59 international pharmacists working in gulf countries. Ninety-five per cent of the total pharmacists had limited $(73 \%)$ or no $(22 \%)$ awareness of such credentials. This was a significant concern that they felt was important for gaining more information. The responses obtained showed preferences towards Board of Pharmacy Specialties (BPS) (83\%), American Society of Health-system Pharmacists (ASHP) certificate (69\%), Society of Infectious Diseases Pharmacy (SIDP) Antimicrobial stewardship certificate programmes (56\%), University of Florida pharmacy certificate programmes (53\%), Medication therapy management programme (MTM) (30\%) and others (0.03\%). Accordingly, the following internet sites concerning BPS, ASHP, SIDP, University of Florida, and MTM were searched, and data retrieved were the eligibility criteria, description of the programmes, topics covered, fees, and other essential particulars.

Relevant peer-reviewed articles sorted had pointed out the international preferences and advantages of specific certificate and certification programmes. During the literature search, articles related to BPS $(n=8), \operatorname{ASHP}(n=8)$, antibiotic stewardship ( $n=1866)$, and MTM $(n=275)$ were observed and collected from Google Scholar, Scopus, and PubMed, but six significant published works that met the criteria were extracted. Reputed certificates and certification programmes that would add value to the pharmacy practices and the pilot study were the primary concern for narrating the review. Despite the numerous pharmacy credentials across countries, BPS, ASHP, SIDP, University of Florida Pharmacy Certificate Programme, and MTM programme were focused here (Figure 1). 


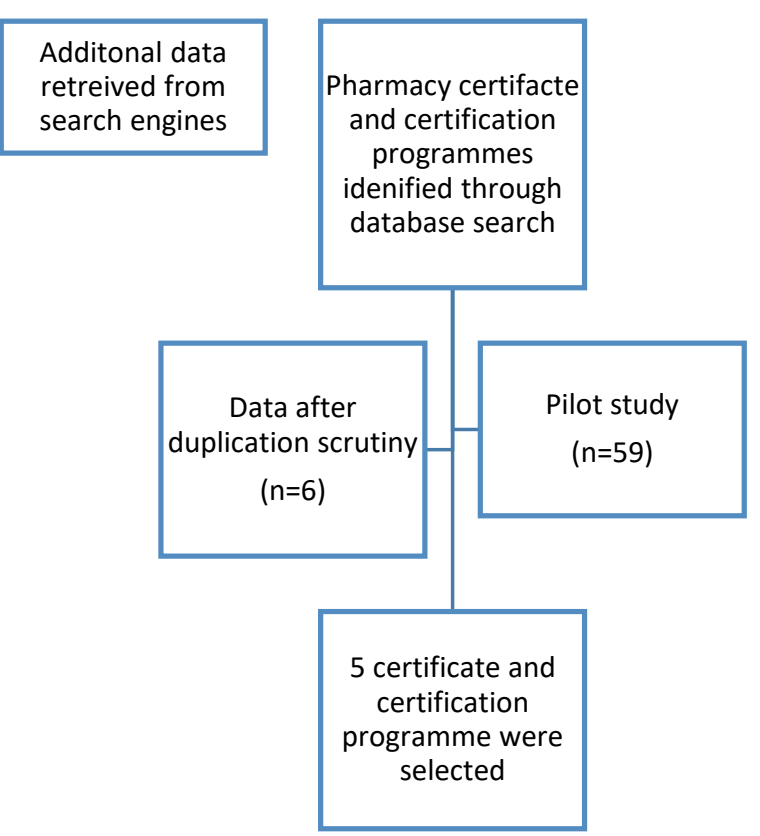

Figure 1: Flow chart specifying the review process

\section{Data analysis}

The information was analysed independently by all the authors and reviewed further for any discrepancies.

\section{Results}

The retrieved information concerning five certificates and certification programmes for international pharmacists were as follows:

\section{Board of pharmacy specialities}

The Board of pharmacy specialities (BPS) serves to advance the profession wherein competent pharmacists are originated. The main objective of specialisation was to cautiously create more focused care for a specific category of patients. Moreover, the BPS certified pharmacist would quickly sink with the other healthcare providers to attenuate and discuss medicine-related matters. The eligibility and recertification requirements are represented in Figure 2.

\begin{tabular}{|l|}
\hline $\begin{array}{c}\text { Eligibility for BPS } \\
\text { certification }\end{array}$ \\
\hline -Applicant's \\
country: Any \\
-Applicant's \\
qualification: \\
Pharmacy degree \\
-Experience: \\
Minimum three \\
years \\
-Examination fees: \\
600 USD \\
-Certification \\
validity: 7 years \\
\end{tabular}
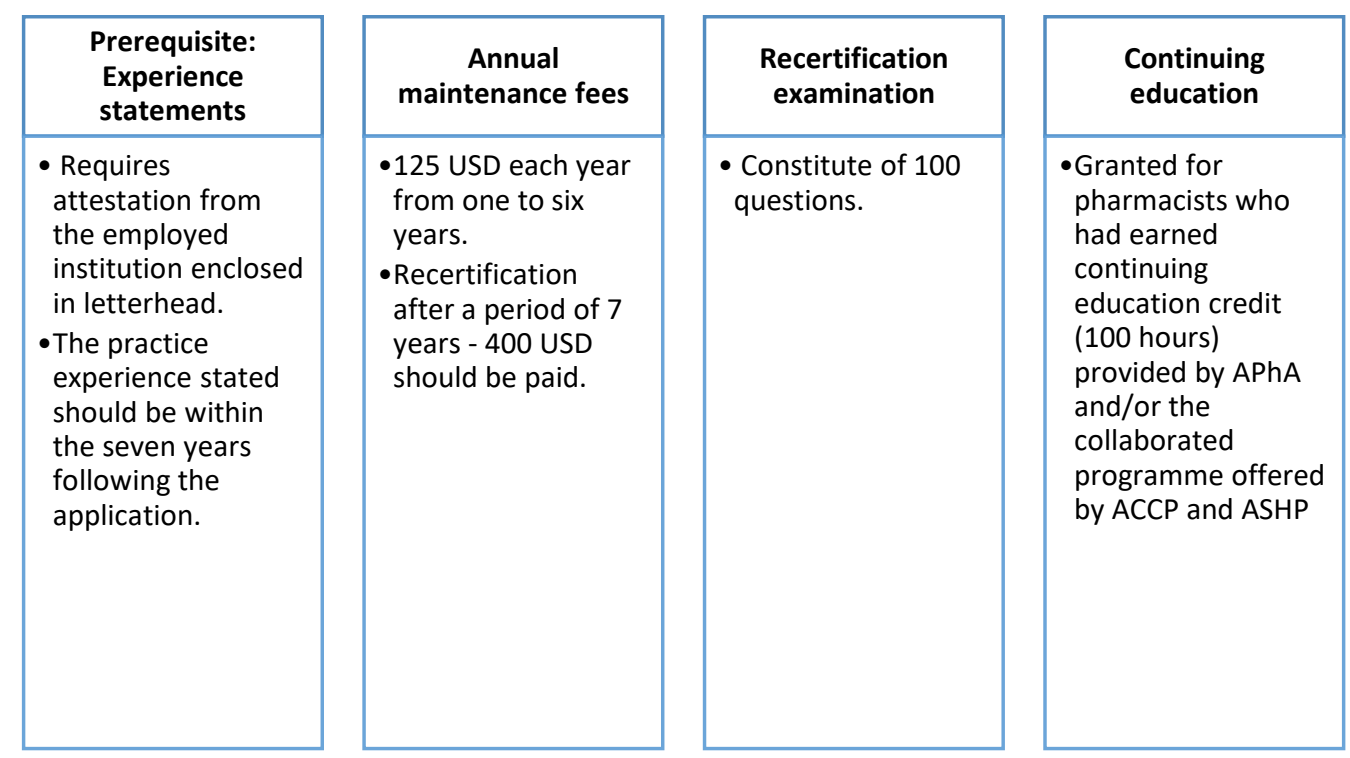

APhA-American Pharmacists Association; ASHP- American Society of Health-System Pharmacists

Figure 2: Board of Pharmacy Specialities pre-requisite and recertification procedures

BPS is offering certification programmes in different specialities to practising pharmacists depending upon their areas of interest (Board of Pharmacy Specialties (BPS) Homepage, n.d.). The following are the specialities (Table I).

\section{University of Florida certification courses}

Since 2011, the University of Florida College of Pharmacy at the United States, a fully accredited pharmacy college by the American Council on Pharmaceutical Education, has offered several online graduate degree programmes ("University of Florida College of Pharmacy (Pharm. D.)," n.d.). The courses (Table II) are designed to maintain and improve professional competence in various practice settings and develop expertise in specialised areas to improve patient-centred care and healthcare delivery (Online Graduate Programmes, College of Pharmacy, University of Florida, n.d.). 
Table I: The salient features and requirements of Board of Pharmacy Specialities Programmes

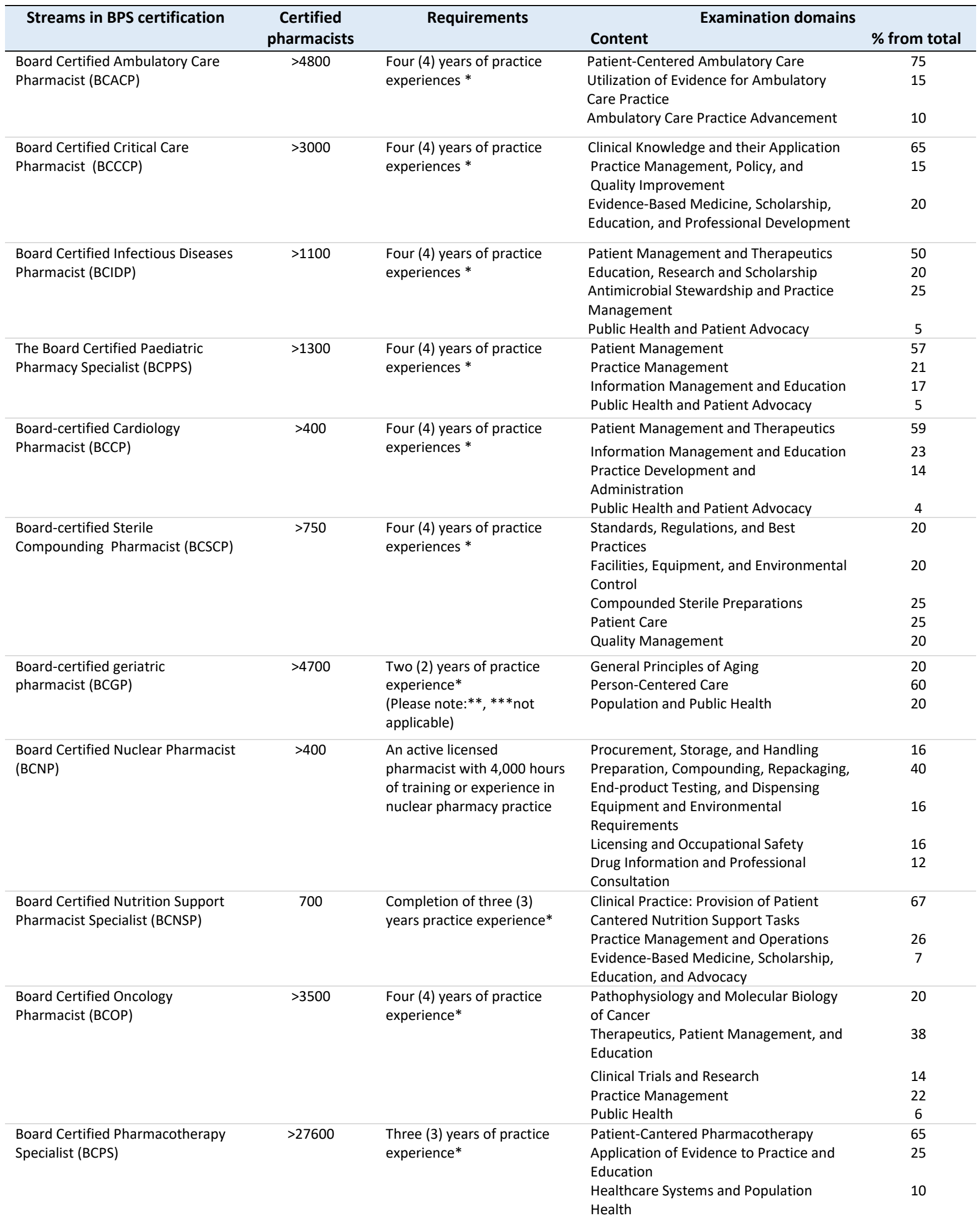


Table I: The salient features and requirements of Board of Pharmacy Specialities Programmes (continued)

\begin{tabular}{|c|c|c|c|c|}
\hline \multirow[t]{2}{*}{ Streams in BPS certification } & \multirow{2}{*}{$\begin{array}{c}\text { Certified } \\
\text { pharmacists }\end{array}$} & \multirow[t]{2}{*}{ Requirements } & \multicolumn{2}{|c|}{ Examination domains } \\
\hline & & & Content & $\%$ from total \\
\hline Board Certified Psychiatric & $>1300$ & Four (4) years of practice & Person-Centered Care & 55 \\
\hline \multirow[t]{2}{*}{ Pharmacist (BCPP) } & & experience* & $\begin{array}{l}\text { Translation of Evidence into Practice } \\
\text { and Education }\end{array}$ & 30 \\
\hline & & & $\begin{array}{l}\text { Healthcare Policy, Advocacy, and } \\
\text { Practice Management }\end{array}$ & 15 \\
\hline \multirow[t]{4}{*}{$\begin{array}{l}\text { Board Certified Transplant } \\
\text { Pharmacist (BCTXP) }\end{array}$} & - & $\begin{array}{l}\text { Completion of four (4) years } \\
\text { of practice experience* }\end{array}$ & $\begin{array}{l}\text { Clinical Skills and Therapeutic } \\
\text { Management }\end{array}$ & 65 \\
\hline & & & $\begin{array}{l}\text { Administration and Practice } \\
\text { Development }\end{array}$ & 15 \\
\hline & & & $\begin{array}{l}\text { Information Management and } \\
\text { Education }\end{array}$ & 15 \\
\hline & & & Public Health & 5 \\
\hline \multirow[t]{3}{*}{$\begin{array}{l}\text { Board Certified Emergency } \\
\text { Medicine Pharmacist (BCEMP) }\end{array}$} & - & $\begin{array}{l}\text { Completion of four ( } 4 \text { ) years } \\
\text { of practice experience* }\end{array}$ & Patient Care/ Management & 75 \\
\hline & & & Practice Management & 15 \\
\hline & & & Education and Research & 10 \\
\hline
\end{tabular}

The requirement is graduation from a pharmacy programme with an active license to practice pharmacy. The experience can be either of the following: 1) *Job Experience; 2) **Completion of PGY1 residency + 1-year practice; 3) Completion of a PGY2 residency in the same discipline. The information was collected from the website on 12 June 2021.

Table II: Salient features and requisites of University of Florida certification courses

\begin{tabular}{|c|c|c|c|c|c|c|}
\hline Name of the certificate & Started on & Course benefit & Remarks & $\begin{array}{l}\text { CE } \\
\text { credit } \\
\text { hours }\end{array}$ & $\begin{array}{l}\text { Activity } \\
\text { fees }\end{array}$ & $\begin{array}{l}\text { Passing } \\
\text { score }\end{array}$ \\
\hline $\begin{array}{l}\text { Collaborative practice } \\
\text { agreement certificate } \\
\text { programme }\end{array}$ & 18 Feb 2021 & $\begin{array}{l}\text { Prepares the pharmacists } \\
\text { to collaborate with a } \\
\text { supervising physician as } \\
\text { established by Florida } \\
\text { law }\end{array}$ & $\begin{array}{l}\text { This programme } \\
\text { meets the } \\
\text { requirements } \\
\text { outlined in Section } \\
465.1865\end{array}$ & $\begin{array}{l}20 \text { hours } \\
(12.0 \\
\text { hours } \\
\text { self- } \\
\text { paced; } \\
\text { Eight- } \\
\text { live, } \\
\text { online) }\end{array}$ & USD 699 & $70 \%$ \\
\hline $\begin{array}{l}\text { Test and treat } \\
\text { certificate programme }\end{array}$ & 18 Feb 2021 & $\begin{array}{l}\text { Prepares the pharmacist } \\
\text { to screen the patients } \\
\text { and treat minor, non- } \\
\text { chronic health conditions } \\
\text { under the supervision of } \\
\text { a physician }\end{array}$ & $\begin{array}{l}\text { This programme } \\
\text { meets the } \\
\text { requirements } \\
\text { outlined in Section } \\
465.1895\end{array}$ & $\begin{array}{l}20 \text { hours } \\
(12.0 \\
\text { hours } \\
\text { self- } \\
\text { paced; } \\
\text { Eight- } \\
\text { live, } \\
\text { online) }\end{array}$ & USD 699 & $70 \%$ \\
\hline $\begin{array}{l}\text { Implementing } \\
\text { pharmacogenomics into the } \\
\text { clinical practice certificate } \\
\text { programme }\end{array}$ & 11 Jan 2021 & $\begin{array}{l}\text { A self placed online } \\
\text { certificate programme } \\
\text { that enhances } \\
\text { pharmacists with the } \\
\text { knowledge essential to } \\
\text { implement } \\
\text { pharmacogenomics into } \\
\text { pharmacy practice }\end{array}$ & $\begin{array}{l}\text { This programme is } \\
\text { approved by the } \\
\text { Florida Board of } \\
\text { Pharmacy for } \\
\text { consultant } \\
\text { pharmacist } \\
\text { recertification credit }\end{array}$ & $\begin{array}{l}25 \text { hours } \\
\text { fully } \\
\text { online }\end{array}$ & USD 699 & N/A \\
\hline $\begin{array}{l}\text { Anticoagulation therapy } \\
\text { management for } \\
\text { pharmacists }\end{array}$ & 30 Dec 2020 & $\begin{array}{l}\text { This programme helps to } \\
\text { prepare the pharmacist } \\
\text { to monitor and manage } \\
\text { anticoagulation therapy }\end{array}$ & $\begin{array}{l}\text { The programme } \\
\text { helps the pharmacist } \\
\text { to be equipped for } \\
\text { the Certified } \\
\text { Anticoagulation Care } \\
\text { Provider (CACP) } \\
\text { exam }\end{array}$ & $\begin{array}{l}18.5 \\
\text { hours } \\
\text { fully } \\
\text { online }\end{array}$ & USD 699 & $70 \%$ \\
\hline $\begin{array}{l}\text { Veterinary pharmacy for } \\
\text { practising pharmacists }\end{array}$ & 30 Dec 2020 & $\begin{array}{l}\text { Prepares pharmacists for } \\
\text { legal counseling } \\
\text { requisite, cautiously } \\
\text { monitoring drug-related } \\
\text { matters, and fill } \\
\text { veterinary prescriptions } \\
\text { with utmost safety }\end{array}$ & $\begin{array}{l}\text { Designed for } \\
\text { pharmacists } \\
\text { interested in } \\
\text { veterinary pharmacy }\end{array}$ & 15 hours & USD 299 & N/A \\
\hline
\end{tabular}

The information was collected from the website on 12 June 2021; N/A, Not available 


\section{American Society of Health-System Pharmacists (ASHP) offers certificate programmes}

The American Society of Health-System Pharmacists (ASHP) offers certificate programmes covering a broad scope of knowledge and skill in different practice areas (Table III). The ASHP professional certificates are a selfguided online programme that guarantees a highquality, practical development opportunity for pharmacy practitioners. The learning modules are $100 \%$ online and presented in an easily understandable format. After completing each module, the participant must pass a thorough exam and earn Accreditation Council for Pharmacy Education (ACPE) accredited continuing education credit for each module. Finally, ASHP shall issue the professional certificate. The primary area covered are clinical topics related to pharmacy practice, general learning units, and sterile compounding. Currently, ASHP offers 20 professional certificate programmes (Table IV) for practising pharmacists, and some more new certificate programmes are expected to be live shortly (Professional Certificate Programmes, n.d.).

\section{Table III: Merits of ASHP certification courses \\ Well-Being and Resilience Certificate \\ - Participants will be able to incorporate systems and human-centred design concepts to change organizations into well-being cultures and individual wellbeing techniques leading to resilience for self and others. \\ Crisis and Pandemic Management Certificate \\ - Through this course, the pharmacist will be able to address the needs of patients and the entire healthcare system related to the druggist at the time of crisis and pandemic situations. The certified person will be able to offer non-pharmacological and pharmacologic interventions to continue a secure and competent workflow at the time of crisis.}

\section{Anticoagulation Certificate}

- The professional would merit with depth knowledge on cases concerning anticoagulants

Pain Management Certificate

- Proficient in pain assessment and its pharmacological and non-pharmacological care would be attained.

Pediatrics Certificate

- Proficiency in caring for the pediatric population is the advantage of the certification.

Diabetes Management Certificate

- The certified pharmacist will be able to evaluate various disease states related to Diabetes. He will be able to deliver quality pharmacologic and non-pharmacologic interventions considering different patient-related factors.

\section{Medication Reconciliation Certificate}

- The outcomes of this course are the expert in carrying out medication history studies and implementing such studies in an institutional setting for improving patient care.

Pharmacy Revenue Cycle Management Certificate

- Expertise in operating regulations, as well as outstanding execution of pharmacy revenue cycle, is the aim of this certificate. Pharmacokinetics Certificate

- The course covers applications of pharmacokinetic theories to monitor, assess and alter the medication regimen for different patients.

Medication Safety Certificate

- Revamping the safe use of medicines in the respective practice setting of the pharmacists as well as other clinical staff is the agenda of the course.

\section{Emergency Medicine Certificate}

- This certification program targets pharmacists who are working with emergency medicine-related clinical activities. Also, the course focuses on evidence-based pharmacologic as well as non-pharmacologic therapy for various ailments.

\section{Nutrition Support Certificate}

- The certified person will be an expert in providing clinical care related to nutrition support for adult patients.

Compounded Sterile Preparations Certificate

- An expert in fundamental medicine compounding techniques as well as up-to-date expertise to manage and lead cleanroom preparation of sterile products in a secure and compliant manner.

Sterile Product Preparation Certificate

- The certified person will be skilful in sterile product preparation in a safe and compliant way. 


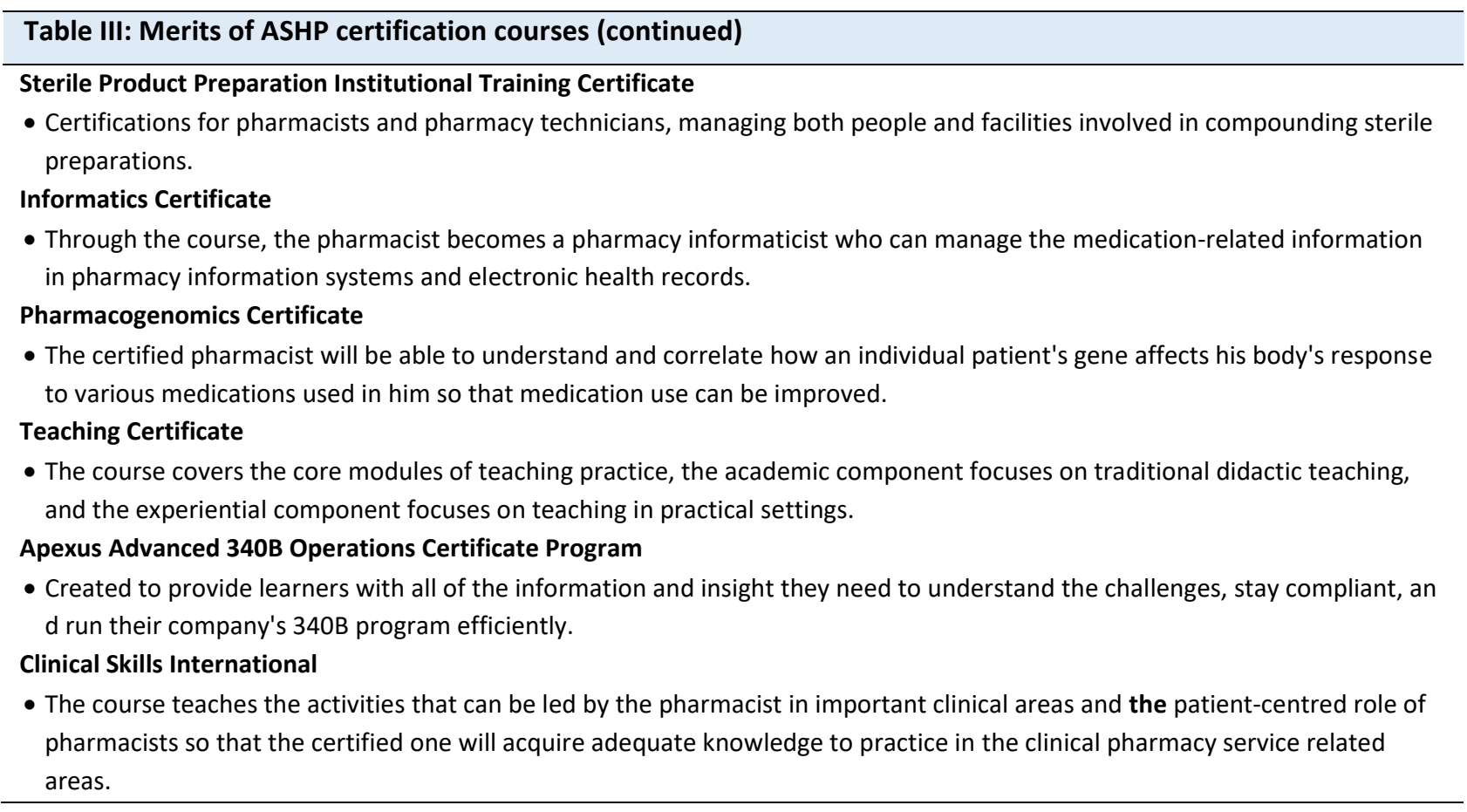

Table IV: The prerequisite for the accomplishment of ASHP certification programmes

\begin{tabular}{|c|c|c|c|c|c|c|c|}
\hline \multirow[t]{2}{*}{ Name of Certificate } & \multirow{2}{*}{$\begin{array}{l}\text { CE } \\
\text { Credit } \\
\text { Hours }\end{array}$} & \multicolumn{2}{|c|}{ Activity fee } & \multirow{2}{*}{$\begin{array}{l}\text { Number of } \\
\text { learning } \\
\text { module }\end{array}$} & \multirow{2}{*}{$\begin{array}{l}\text { Number of } \\
\text { questions in } \\
\text { exam }\end{array}$} & \multirow{2}{*}{$\begin{array}{l}\text { Passing } \\
\text { score }\end{array}$} & \multirow{2}{*}{$\begin{array}{l}\text { Exam } \\
\text { attempts } \\
\text { permitted }\end{array}$} \\
\hline & & $\begin{array}{l}\text { ASHP } \\
\text { Member }\end{array}$ & $\begin{array}{c}\text { Non } \\
\text { member }\end{array}$ & & & & \\
\hline $\begin{array}{l}\text { Crisis and Pandemic Management } \\
\text { Certificate }\end{array}$ & 25.25 & USD 445 & USD 545 & 10 & 100 & $80 \%$ & Unlimited \\
\hline Anticoagulation Certificate & 32 & USD 445 & USD 545 & 12 & 75 & $80 \%$ & Unlimited \\
\hline Pain Management Certificate & 21.5 & USD 445 & USD 545 & 9 & 90 & $80 \%$ & Unlimited \\
\hline Pediatrics Certificate & 27 & USD 445 & USD 545 & 9 & 130 & $80 \%$ & Unlimited \\
\hline Diabetes Management Certificate & 33 & USD 445 & USD 545 & 12 & 120 & $80 \%$ & Unlimited \\
\hline Medication Reconciliation Certificate & 15 & USD 445 & USD 545 & 7 & 50 & $80 \%$ & Unlimited \\
\hline $\begin{array}{l}\text { Pharmacy Revenue Cycle Management } \\
\text { Certificate }\end{array}$ & 16.5 & USD 445 & USD 545 & 9 & N/A & $80 \%$ & Unlimited \\
\hline Medication Safety Certificate & 40 & USD 445 & USD 545 & 15 & 100 & $80 \%$ & Unlimited \\
\hline Emergency Medicine Certificate & 27 & USD 445 & USD 545 & 11 & 115 & $80 \%$ & Unlimited \\
\hline Nutrition Support Certificate & 19.25 & USD 445 & USD 545 & 11 & 100 & $80 \%$ & Unlimited \\
\hline $\begin{array}{l}\text { Compounded Sterile Preparations } \\
\text { Certificate }\end{array}$ & 38 & USD 445 & USD 545 & 16 & 125 & $80 \%$ & Unlimited \\
\hline Sterile Product Preparation Certificate & 29 & USD 445 & USD 545 & 14 & 90 & $80 \%$ & Unlimited \\
\hline $\begin{array}{l}\text { Sterile Product Preparation Institutional } \\
\text { Training Certificate }\end{array}$ & 29 & USD 445 & USD 545 & 14 & N/A & N/A & Unlimited \\
\hline Informatics Certificate & 21 & USD 445 & USD 545 & 20 & 70 & $80 \%$ & Unlimited \\
\hline Pharmacogenomics Certificate & 20 & USD 445 & USD 545 & 8 & 85 & $80 \%$ & Unlimited \\
\hline Teaching Certificate & 16.5 & USD 395 & USD 495 & 3 tracks & $\mathrm{N} / \mathrm{A}$ & $80 \%$ & N/A \\
\hline Clinical Skills International & 22 & USD 395 & USD 495 & 17 & 41 & $70 \%$ & Unlimited \\
\hline
\end{tabular}

The information were collected from the website on 13 June 2021; N/A not available 


\section{Antimicrobial Stewardship Certificate Programme}

The Society of Infectious Diseases Pharmacists offers three programmes emphasising the pharmacists' role in antibiotics utilisation (Table V). All the programme consists of three phases that can be accomplished within the home or practical atmosphere (SIDP -
Stewardship Certificate, n.d.). The first and second phase of the SIDP certificate programme comprises learning modules. Later, each participant should disseminate the information gained to their fellow professionals and aid them on how to publicise their antibiotic stewardship procedures (Figure 3).

Table V: Phases, focus, and advantages of SIDP programs

\begin{tabular}{|c|c|c|c|c|c|}
\hline Name & Focuses & Phases & Cost & $\begin{array}{l}\text { Discount } \\
\text { available }\end{array}$ & $\begin{array}{l}\text { Time to } \\
\text { complete }\end{array}$ \\
\hline $\begin{array}{l}\text { SIDP Antimicrobial Stewardship } \\
\text { Certificate for acute care } \\
\text { SIDP Low- and Middle-Income } \\
\text { Country (LMIC) Antimicrobial } \\
\text { Stewardship Certificate } \\
\text { Program } \\
\text { SIDP Long-Term Care (LTC) } \\
\text { Antimicrobial Stewardship } \\
\text { Certificate Programme }\end{array}$ & $\begin{array}{l}\text { Essentials of clinical } \\
\text { microbiology, pharmacology, } \\
\text { pharmacokinetics, } \\
\text { pharmacodynamics, and } \\
\text { infectious disease state } \\
\text { management, skills needed to } \\
\text { establish, implementation of the } \\
\text { intervention, evaluate the } \\
\text { effectiveness of antimicrobial } \\
\text { stewardship program }\end{array}$ & $\begin{array}{l}\text { Phase 1: } 28 \text { hours or } 2.8 \text { CEUs) } \\
\text { Phase } 2: 6-9 \text { hours or } 0.6-0.9 \\
\text { CEUs } \\
\text { Phase } 3: 10 \text { hours or } 1.0 \text { CEU) } \\
\text { Phase 1: } 20.25 \text { hours, } 2.025 \text { CEU } \\
\text { Phase 2: (Combination of Live } \\
\text { and Home-Study webinars) } 4.25- \\
\text { 8.75 hours, } 0.425-0.875 \text { CEU } \\
\text { Phase } 3: 10 \text { hours or } 1.0 \text { CEU }\end{array}$ & $\begin{array}{l}\text { USD } \\
750 \\
\\
\text { USD } \\
850\end{array}$ & $\begin{array}{l}\text { Group } \\
\text { registration } \\
\text { and Low- } \\
\text { Mid Income } \\
\text { Countries }\end{array}$ & $\begin{array}{l}\text { Phase } 1 \text { and } 2 \\
\text { within } 8 \\
\text { months } \\
\text { Phase } 3 \text { within } \\
12 \text { months of } \\
\text { registration }\end{array}$ \\
\hline
\end{tabular}

The information was collected from the website on 15 June 2021; CEU- Credit hour explanation.
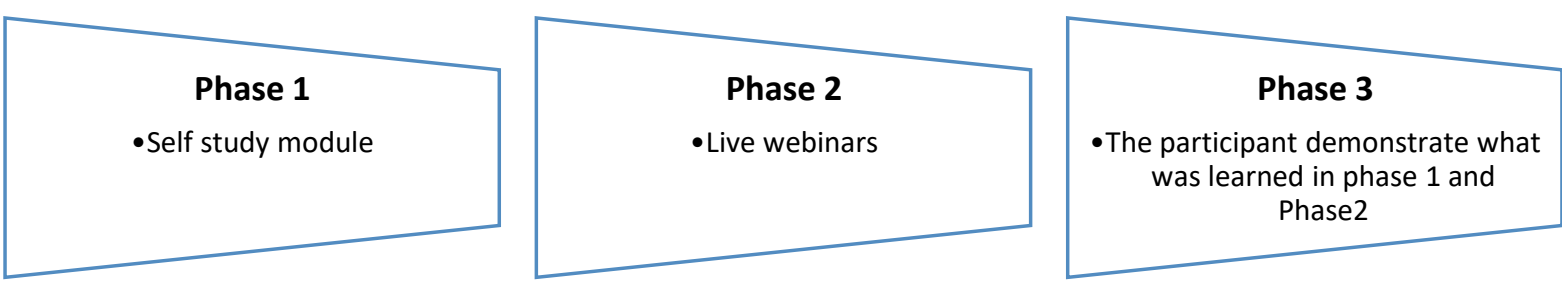

Figure 3: The three phases in Antimicrobial Stewardship Certificate Programme

\section{Board Certification in Medication Therapy Management (BCMTM)}

The non-profit and independent organisation is the first and the only authorised medication therapy management (MTM) certification host for pharmacists. They assure the public that the certified pharmacist possesses the skill and knowledge of high-quality patient care for therapy optimisation ("MTM Certification," n.d.). BCMTM examination constitutes

\begin{tabular}{|l|}
\hline About examination \\
* Four hour \\
$* 200$ multiple choice questions \\
\hline
\end{tabular}

\begin{tabular}{|l|}
\hline Partitioning in the \\
examination \\
I. Defining MTM and Translating \\
MTM into practice (13\%) \\
II. Pharmacotherapy (62\%) \\
III. Fundamentals of \\
pharmacogenomics (5\%) \\
IV. Patient care advocacy (13\%) \\
V. Documentation and billing \\
(7\%) \\
\hline
\end{tabular}

200 multiple choice questions that should be completed within four hours. Pharmacotherapy (62\%), medication therapy management (13\%), fundamentals of pharmacogenomics (5\%), patient care advocacy (13\%), and documentation and billing (7\%) are the five focusing areas. The initial application fee is 450 USD, and for re-test, it would become 200 USD. Individuals who pass the exam would gain the certification upon achieving the required mark that may vary slightly from each version (Figure 4).

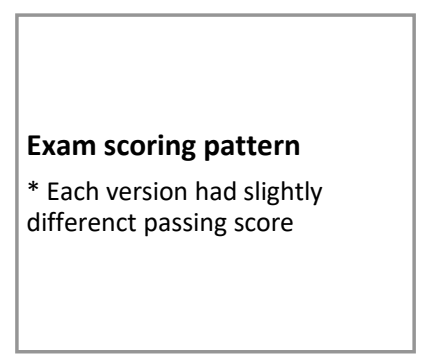

Application fees

* Initial certification fee - USD 450

* Non United States resident USD 80

Figure 4: Salient details regarding BCMTM examination 


\section{Discussion}

BPS, ASHP, SIDP, University of Florida Pharmacy certificate programme, and MTM programme were the five standard certificates and certification programmes discussed here. The preference was weighed onto BPS certification credentials than others (Connor \& Hamilton, 2010). Alqahtani and authors underwent a knowledge attitude study on pharmacists and pharmacy academicians in a Middle East country. They observed $55.2 \%$ and $48.2 \%$ of respondents to have good knowledge and attitude concerning BPS certification (Alqahtani et al., 2020). This reflects their concern towards the professional update and, on the other hand, demands for widening awareness among the larger community. Enhancement in clinical skills should be each pharmacist's motif. However, a lack of additional consideration from the employers in terms of monetary or professional growth and inadequate time led them to drop from such programmes. Moreover, pharmacists retained in community settings were not interested and claimed that employees in clinical components would only benefit through board certification (Goldenshteyn et al., 2020). Studies emphasise the re-equip potential with a continuing education programme on the pharmacy discipline regardless of the work environment(Mattingly \& Mattingly II, 2018). A US-based electronic survey was performed to identify the perception of pharmacy residents towards the programme. It was noted that 93\% preferred to be board-certified pharmacotherapy specialists followed by oncology and psychiatry credentials. Even though developed countries do promote gaining credentials, there were more than half samples that did not want to pursue any (American College of Clinical Pharmacy Board of Regents \& Maddux, 2013). Conveying and convincing the importance of being a certified pharmacist is quite essential in this current era, and the pharmacy council across the world should implement strategies to accomplish this task.

The preference of young generations to take up residency programmes and further to appear for certification programmes has been noticed nowadays. This is a positive sign for clinical pharmacy precipitated by the change in pre-requisite criteria for the official examinations (Silvia et al., 2020). Pharmacists can significantly contribute to long-standing disease conditions. A survey by Silvia and authors depicted that certified psychiatric pharmacists were authorised $(46.5 \%)$ to prescribe during practice under the clinician's supervision. This service was not reserved for psychiatric patients alone but also for all patients of the hospital. The entrust was established through the knowledge and skills acquired through certification programmes. Stating such achievements to the pharmacy professionals would elevate their attitude to prepare for the credentials.

The certified pharmacist can implement advanced operation procedures and reforms in their expertise. One such example put forward by Westmoreland and authors wherein they picturised the clinical interventions suggested and implemented by certified pharmacists in the critical care department imparted profound health outcomes. The awareness concerning newer techniques and policies is certainly mandatory for installing a professional intervention; certificate and certification programmes serve the task that collectively contributions to patient betterment (Westmoreland et al., 2021). Johnson and the authors researched on certified ambulatory care pharmacists that the practice preferences domain of the programme is clinically relevant and patient-focused (Johnson et al., 2021). This justifies the quality of the certification programmes in healthcare, hosting pharmacists in actively involving and establishing treatment guidelines and standards for new disease conditions and re-framing the existing illness. Antibiotics being a prime concern, collaborative efforts from the American Society of Health-system pharmacist and Society of Infectious Diseases Pharmacists had brought quite suitable stewardship policies (Rybak et al., 2020). Their suggestions were valuable in an era where contagious and superspreader infections are invading. Similarly, ASHP, in association with the American college of clinical pharmacy critical care practice and research network, has recommended strategies to improve patient care (Lat et al., 2020). Enhancement of the quality of medical services should be the concern of every healthcare professional and can be achieved basically through certificate and certification programmes. Each certificate and certification programme has the potency to upgrade the pharmacists to be skilful and specialise in their field. Moreover, promoting youngsters for acquiring authentic worth doing credentials is the sole responsibility of experienced and certified pharmacists.

\section{Conclusion}

Pharmacy practice is undoubtedly reforming, and the need for further updates is essential through which ultimate patient care is accomplished. This relied upon pharmacists' attitudes towards continuing education programmes. The article serves as a guide for international pharmacists to know about certificates and certification programmes. Most sought out pharmacy credentials such as BPS, SIDP, MTM, ASHP, and University of Florida pharmacy certificate 
programmes were discussed here and would asset them in gaining professional advancements.

\section{Disclaimer}

The information provided in this article is for reference purposes only. It has been collected from the respective websites of various pharmacy professional certificates and certification programs. The details in the website are subjected to changes or updates in the future for which the authors have no influence.

\section{References}

Abd El-Aziz, T.M., \& Stockand, J.D. (2020). Recent progress and challenges in drug development against COVID-19 coronavirus (SARS-CoV-2)-An update on the status. Infection, Genetics and Evolution, 83, 104327. https://doi.org/10.1016/j.meegid.2020.104327

Alqahtani, R., Alzahrani, M., Qandil, A., Alkatheri, A., Shawaqfeh, M., \& Albekairy, A. (2020). Knowledge and Attitude towards Board of Pharmacy Specialties (BPS) Certification among Pharmacists and Pharmacy Students: A Cross Sectional Survey. International Journal of Medical Research \& Health Sciences, 9, 18-24

American College of Clinical Pharmacy Board of Regents, \& Maddux, M.S. (2013). Board of Regents commentary. Qualifications of pharmacists who provide direct patient care: Perspectives on the need for residency training and board certification. Pharmacotherapy, 33(8), 888-891. https://doi.org/10.1002/phar.1285

Blouin, R.A., \& Adams, M.L. (2017). The Role of the Pharmacist in Health Care: Expanding and Evolving. North Carolina Medical Journal, 78(3), 165-167. https://doi.org/10.18043/ncm.78.3.165

Board of Pharmacy Specialties (BPS) Homepage. (n.d.). (2021). Board of Pharmacy Specialties. Available at: https://www.bpsweb.org/

Connor, K.A., \& Hamilton, L.A. (2010). Pursuing Board of Pharmacy Specialties certification. American Journal of Health-System Pharmacy, 67(14), 1146, 1150-1151. https://doi.org/10.2146/ajhp090209

Glans, M., Kragh Ekstam, A., Jakobsson, U., Bondesson, Å., \& Midlöv, P. (2020). Risk factors for hospital readmission in older adults within 30 days of discharge - a comparative retrospective study. BioMed Central Geriatrics, 20(1), 467. https://doi.org/10.1186/s12877-020-01867-3

Goldenshteyn, F., Dopheide, J., \& Lou, M. (2020). Do pharmacist employers prefer or require board certification? Journal of the American Pharmacists Association, 60(1), 6671. https://doi.org/10.1016/j.japh.2019.09.015

Johnson, S.G., Muckle, T., Guffey, J., \& Patel, R. (2021). The continued evolution of the ambulatory care pharmacy specialty: Results and analysis from the 2019 Role
Delineation Study. Journal of the American Pharmacists Association, 61(3), 258-265. https://doi.org/10.1016/j.japh.2021.01.008

Kaiser, M.S., Al Mamun, S., Mahmud, M., \& Tania, M.H. (2021). Healthcare Robots to Combat COVID-19. In K. C. Santosh \& A. Joshi (Eds.), COVID-19: Prediction, DecisionMaking, and its Impacts (pp. 83-97). Springer. https://doi.org/10.1007/978-981-15-9682-7_10

Kak, N., Burkhalter, B., \& Cooper, M.-A. (n.d.). Measuring the Competence of Healthcare Providers. 28

Lat, I., Paciullo, C., Daley, M.J., MacLaren, R., Bolesta, S., McCann, J., Stollings, J. L., Gross, K., Foos, S. A., Roberts, R. J., Acquisto, N. M., Taylor, S., Bentley, M., Jacobi, J., \& Meyer, T. A. (2020). Position Paper on Critical Care Pharmacy Services: 2020 Update. Critical Care Medicine, 48(9), e813-e834. https://doi.org/10.1097/CCM.0000000000004437

Mattingly, A.N., \& Mattingly II, T.J. (2018). Advancing the role of the pharmacy technician: A systematic review. Journal of the American Pharmacists Association, 58(1), 94108. https://doi.org/10.1016/j.japh.2017.10.015

MTM Certification. (n.d.). (2021). National Board of Medication Therapy Management. Available at: https://www.nbmtm.org/about/mtm-certification/

Ofori-Asenso, R., \& Agyeman, A.A. (2016). Irrational Use of Medicines-A Summary of Key Concepts. Pharmacy, 4(4), 35. https://doi.org/10.3390/pharmacy4040035

Online Graduate Programmes » College of Pharmacy » University of Florida. (n.d.). (2021). Available at: https://pharmacy.ufl.edu/education/online-msprogrammes/

Professional Certificate Programmes. (n.d.). (2021) Available at: https://www.ashp.org/Professional-

Development/Professional-Certificate-Programmes

Rahman, R., Ross, A., \& Pinto, R. (n.d.). The critical importance of community health workers as first responders to COVID-19 in USA. Health Promotion International. https://doi.org/10.1093/heapro/daab008

Rodgers, R.M., Gammie, S.M., Loo, R.L., Corlett, S.A., \& Krska, J. (2016). Comparison of pharmacist and public views and experiences of community pharmacy medicines-related services in England. Patient Preference and Adherence, 10, 1749-1758. https://doi.org/10.2147/PPA.S112931

Rybak, M.J., Le, J., Lodise, T.P., Levine, D.P., Bradley, J.S., Liu, C., Mueller, B.A., Pai, M.P., Wong-Beringer, A., Rotschafer, J. C., Rodvold, K.A., Maples, H.D., \& Lomaestro, B. (2020). Therapeutic Monitoring of Vancomycin for Serious Methicillin-resistant Staphylococcus aureus Infections: A Revised Consensus Guideline and Review by the American Society of Health-system Pharmacists, the Infectious Diseases Society of America, the Pediatric Infectious Diseases Society, and the Society of Infectious Diseases Pharmacists. Clinical Infectious Diseases: An Official Publication of the Infectious Diseases Society of America, 71(6), 1361-1364. https://doi.org/10.1093/cid/ciaa303 
Siddique, S., \& Chow, J.C.L. (2021). Machine Learning in Healthcare Communication. Encyclopedia, 1(1), 220-239. https://doi.org/10.3390/encyclopedia1010021

SIDP - Stewardship Certificate. (n.d.). (2021). Available at: https://sidp.org/Stewardship-Certificate

Silvia, R.J., Lee, K.C., Bostwick, J.R., Cobb, C.D., Goldstone, L. W., Moore, T.D., Payne, G.H., \& Ho, J.L. (2020). Assessment of the current practice of psychiatric pharmacists in the United States. Mental Health Clinician, 10(6), 346-353. https://doi.org/10.9740/mhc.2020.11.346

University of Florida College of Pharmacy (Pharm. D). (n.d.). (2021). Accreditation Council for Pharmacy Education. Available at: https://www.acpe-accredit.org/faqitem/university-of-florida-college-of-pharmacy-pharmd/

Westmoreland, K., Franck, J.B., \& Franck, A.J. (2021).

Prescribing and documentation by critical care clinical pharmacy specialists with around-the-clock staffing: A single-center evaluation. Journal of the American college of clinical pharmacy, 4(4), 435-440.

https://doi.org/10.1002/jac5.1389

Zogas, A., Gillespie, C., Kleinberg, F., Reisman, J.I., Ndiwane, N., Tran, M.H., Ourth, H.L., Morreale, A.P., Miller, D.R., \& McCullough, M.B. (2021). Clinical Pharmacist Integration Into Veterans' Primary Care: Team Members Perspectives. The Journal of the American Board of Family Medicine, 34(2), 320-327.

https://doi.org/10.3122/jabfm.2021.02.200328 